Cite as: Peršak, N. and Di Ronco, A. (2017). Urban space and the social control of incivilities: perceptions of space influencing the regulation of anti-social behaviour. Crime, Law and Social Change. doi: https://doi.org/10.1007/s10611-017-9739-6.

\title{
Urban space and the social control of incivilities: perceptions of space influencing the regulation of anti-social behaviour
}

\author{
Nina Peršak ${ }^{1}$ and Anna Di Ronco ${ }^{2}$
}

\section{Introduction}

The increasing regulation and social control of incivilities across Europe is a prime example of a shift in social control from the notion of crime towards broader notions of disorder and other sub-criminal behaviour (Garland 2001; Zedner 2009; Pleysier 2015; Peršak 2016a). Incivilities, also known under other names, such as anti-social behaviour, disorder, quality-oflife crimes, public nuisance and petty offences, encompass a variety of conduct from littering and vandalism to public drunkenness, aggressive begging, noisy neighbours and so forth. They have become construed, both at the local and the national levels, as a risk to future crime and as such something to be managed, or better yet, criminalised. Although some incivilities may be harmful and thus legitimately proscribed (such cases have mostly already been criminalised in some way or another), many others represent only trivial and fleeting annoyance to some (although not necessarily to others, as emotional responses are subjective) or a simple violation of a rule, without causing any harm, that is, objective setback to one's legitimate interests (Peršak 2007a; Simester and von Hirsch 2011; Peršak 2014). Drawing on a discourse inherited from the 'broken windows' theory (Wilson and Kelling 1982), it is the risk of incivilities or their assumed propensity to grow into more serious crime that often guides their criminalisation, even though sometimes indirectly through administrative or civil law. ${ }^{3}$ When they are conceptualised as a conduct that causes or may cause alarm, harassment or distress to others (as the anti-social behaviour has been defined in England and Wales, for example), the vagueness and, in particular, the subjectivity of it also highlight the significance of people's perceptions in the definition of incivilities.

A recent comparative work highlighted, among others, the role that space (management) plays in the social control of incivilities across European countries (Peršak 2016b). Zoning, for example, is a strategy used in Budapest, Hungary, to prevent incivilities said to arise from the behaviour of the homeless (such as going through trash and sleeping rough) by prohibiting the homeless in certain areas of the city - areas that belong to city centre and attract tourists. The importance placed on the commercial attractiveness of urban spaces in Budapest was one of the important factors leading to the criminalisation of this particularly vulnerable group (Podoletz 2016). Similar place restrictions have been used in the US to "banish" the undesirable element from specific zones (Beckett and Herbert 2009) or in the UK to prohibit offenders from accessing certain places where they have previously engaged in anti-social conduct. In England and Wales, the prohibition to enter certain areas could be stipulated as a condition in the anti-

\footnotetext{
${ }^{1}$ Institute for Criminal-Law Ethics and Criminology, Ljubljana, Slovenia; Institute for Advanced Study, Central European University, Budapest, Hungary; nina.persak@criminstitute.org; PersakN@ceu.edu.

2 Department of Sociology, University of Essex, Colchester, UK; a.dironco@essex.ac.uk.

3 In Belgium, for example, incivilities are tackled with "municipal administrative sanctions" (gementelijke administratieve sancties); in Germany and Slovenia, they are mostly considered violations (Ordnungswidrigkeiten, prekrški), which form part of the criminal law, even though they are not criminal offences in the strict sense. Antisocial behaviour orders (ASBOs), massively used throughout England and Wales since 1999, before the new antisocial behaviour legislation of 2014 coming into force, were civil-law orders, when - if breached - gained a criminal law nature.
} 
social behaviour order, which, if breached, could lead to imprisonment. After the adoption of the Anti-social Behaviour, Crime and Policing Act 2014, the prohibition to enter certain areas can be postulated as a condition in the civil injunction or become a focus of dispersal powers (direction excluding a person from an area) or of a public space protection order.

However, the space is not perceived in a uniform way. Different cultural meanings, values (Di Ronco 2014, 2016), social and media representations (Peršak 2007b, 2016c) inform our perceptions of space and of activities performed within it. Considering contemporary urban orders are increasingly governed through space (Engle Merry 2004) instead of, or in addition to, being governed through punishment, and considering that it is often the perceptions of space rather than the physical space itself that matter in terms of the social reaction to (uncivil) behaviour in a particular urban space, one could argue that perceptions of space should become an object of criminological and (criminal) policy investigation in their own right. The central aim of this article is to examine how urban space and perceptions of urban space (including the perceptions and spatialities of crime and disorder) can affect the social control in the area of incivilities. To this end, we first inspect the existing criminological literature, particularly within the group of the socio-spatial studies that emphasise the importance of culture and values in the interaction with the social control. Partly drawing on examples from our previous studies and on studies carried out in other disciplines, such as in urban sociology, geography and psychology, we then suggest that people's perceptions of urban space (which are influenced by history, cultural symbols and values, and emotions) affect their perceptions of incivilities, while the latter often determine or at least importantly contribute to the shaping of the social control of incivilities. We further highlight the role of gentrification as a medium consolidating different socio-economic groups in their vision of city development and support for spatial governmentality, and as a tool of social control in itself. The paper concludes by arguing that socio-spatial criminological research should draw (at least more frequently and substantially) on other disciplines in order to obtain a more complete and integrated analysis of the perceptions of the space surrounding us and of the behaviour (and social control) that follows, and by discussing implications of this for the possible future, more integrated and interdisciplinary research on the social control of incivilities in the city.

\section{Socio-spatial (criminological) research}

Anthony Bottoms (2012) referred to three main areas of scholarly research, falling within the heading of socio-spatial criminology, which are concerned with analysing and explaining crime and disorder in urban space. The first group of socio-spatial studies has focused on the spaces where crime and disorder occur the most (hot spots) and on the crime prevention mechanisms that are designed to reduce their incidence in such city areas. The second group is concerned with the analysis of the social structures and dynamics of problematic neighbourhoods as well as with their effects on the (criminal or compliant) behaviour of their residents. The third group of writings, which has only recently emerged, mostly within the ambit of cultural criminology, has emphasised the importance of including cultural values and symbols in the study of perceptions and social control of urban crime and disorder (Bottoms 2012).

This third group of socio-spatial criminological scholarship seems particularly relevant to the purposes of this paper, as it emphasises the importance of cultural values and symbols to explain perceptions of incivilities, which (as will be elaborated below) are important to the purpose of understanding social control against urban disorder. In contrast with first two areas of socio-spatial-criminology, which have mainly addressed urban spaces with a high incidence of crime and disorder, these third group of studies may also provide a more complete picture of crime and incivilities in the city, as also studied crime and disorder in wealthy and recently redesigned, re-planned areas of the city. The latter areas are not necessarily the urban hot spots of crime and disorder; however, they tend to be the privileged sites of social control, as they are usually the spaces where dominant majorities live, work and shop. 
Within this last group of socio-spatial writings, different conceptualisations of space have been developed. Hayward (2004), for example, has theorised the occurrence of crime and disorder in the city and, especially, in regenerated urban areas where consumption and pleasure activities (which often co-exist with disorder) are sought after. On his account, societal attitudes and social control responses tend to vary in these regenerated spaces according to their uses (or to the uses that are "approved" by the mainstream society). Uncivil behaviour is more tolerated in regenerated spaces devoted to business and to the night entertainment, whereas this is less so in big city centres where upper and middle classes tend to live and shop (Hayward 2004: 185-195). A number of cultural criminologists have also studied the influence of newly emerged subjective states of hedonism and cultural practices, mainly raised from the current consumerist culture, on disorder and practices of social control implemented against in revitalised areas of pleasure such as night-time districts (Maesham 2004; Maesham and Brein 2005; Hayward and Hobbs 2007). In addition, they have critically addressed the regulatory/penalising practices implemented against groups that are thought by majority groups not to show enough consumption potential, such as homeless and young people (Coleman 2005; Hayward and Yar 2006; Martin 2009).

Cultural criminological accounts of urban crime and disorder have also framed urban space as a locus of exclusion and penalisation of groups that the dominant majorities perceive as having an alternative, subcultural style, such as graffiti writers (Ferrell 1995, 1997), bikers (Ling and Bracey 1995), and gangs (Miller 1995). Miller (1995), for example, highlighted how style in terms of hairstyle, clothing, tattooing, hand signs and gestures, non-verbal communication and the use of graffiti not only shapes the identity of gang members; markers of style are said to be recognised outside the gang and to be reacted upon by criminal justice actors through criminalisation.

Some researchers have focused on how the experiences of certain groups of people in urban space translate into their perceptions and representations of that space. Within the literature on the Night-Time Economy, which collects writings from many disciplines including urban geography and (cultural) criminology, research has been conducted, mostly by urban geographers, to inspect, for example, how drinkers emotionally and bodily experience (also through social interaction) drinking and alcohol-related disorderly behaviour in the urban space, with space being an element influencing their perceptions (Jayne, Valentine and Holloway 2008, 2012; Jayne and Valentine 2016). ${ }^{4}$ Similar is emphasised by the studies in urban geography on the performative representation of space of, for example, graffiti writers, street artists, skaters, free-runners, and street performers, who are thought to have a different perception of the urban space than the powerful majorities and to contribute, with their actions and behaviour, to the shaping or changing of the image and general representation of the urban space (see, for example, Hubbard 2006).

All these studies based their selection and categories of various urban areas on different criteria. Hayward (2004), Coleman (2005), Maesham and Brain (2005), and Hayward and Hobbs (2007), among others, have based it on a consumption/pleasure criterion, which identifies space as a site where underperforming individuals (e.g., young people and homeless), and individuals who are perceived to act uncivilly while pursuing hedonism (e.g., drinkers), are intensively monitored and penalised (especially in areas where dominant majorities reside and shop). Ferrell (1995, 1997), Miller (1995), Ling and Bracey (1995) have relied on a policing/social control criterion, and conceptualised space as a locus of penalisation of individuals and groups perceived to have a specific subcultural style. Jayne and colleagues (Jayne, Valentine and Holloway 2008, 2012; Jayne and Valentine 2016) have built upon an idea of space that is informed by a "personal lived-in" criterion, where space is an element that interacts in, and shapes, drinkers' (individual and collective) drinking experience.

\footnotetext{
4 The physical layout of bars and public spaces, including their opportunities to sit, stand and move, the availability of toilet facilities, the proximity of other people etc., have been found, for example, to influence drinkers' experiences of drinking and drunkenness in night-time locations (Jayne, Valentine and Holloway 2012).
} 
While it is clear from this literature review that cultural socio-spatial criminological research has considered the perceptions of incivilities (and of "uncivil people") in its analysis of social control of crime and deviance in the urban space, it analysed them mostly in terms of the penalising/excluding effects that the perceptions of powerful societal groups have on minority populations or on people thought to behave "inappropriately" in certain city areas, while paying much less attention to the perceptions of penalised groups. The analysis of the perceptions of certain targeted groups (e.g., street drinkers, skaters etc.) has mostly been carried out by urban geographers, rather than by (cultural) criminologists. This perhaps explains why the criminological analysis of the link between such perceptions and the regulation of incivilities is not particularly profound and illuminating.

What is further underexplored is the symbolism of certain urban spaces and its criminological relevance, i.e. relevance for the selection of the type and of the severity of the regime of urban social control to be applied in various city areas. Whereas many cultureoriented authors have emphasised the symbolic significance of space, they tend to see it through the lens of (late modern) consumerist culture. They have highlighted, for example, the criminogenic pressures that the spatial symbols of the contemporary consumerist culture such as newly built architectures of consumption (e.g. shopping malls and arcades) and their (consumerist) imagery have on individuals (Hayward 2004; Hall et al. 2008). ${ }^{5}$ However, the symbolic meaning or significance of space is also linked to other, historical, architectural and wider social and cultural or context-specific values and dynamics. For example, gentrification processes, physically or architecturally transforming many city centres, have often, rather than entirely replacing the old, added new, consumption-oriented buildings like shopping malls next to relatively old buildings, ${ }^{6}$ particularly when the latter held a specific architectural symbolism through which they were perceived and understood. So far, however, such wider social, historical and architectural factors and dynamics have mostly been studied by other disciplines, such as urban sociology and geography, whose knowledge (e.g. on gentrification) has only marginally penetrated into mainstream criminology. In the remaining part of this article, we aim to help locate some such knowledge gaps and suggest how future research could fill them by arguing also for a bigger interdisciplinary involvement of criminology or more fluid knowledge transfer between the relevant social science disciplines.

\section{Perceptions at the intersections: space - incivilities - regulation}

\subsection{Perceptions of space and perceptions of incivilities}

Perceptions of incivilities, as well as perceptions of urban social problems in general, matter as they often influence how (well) urban dwellers feel about living in their city (Goffman 1971). Similar to the fear of crime, which affects how people behave, where they go, whether they avoid some places in the city, how they comport themselves, what they dress and so forth, perceptions of incivilities can trigger their fear of victimisation (Sampson and Raudenbush 2004), make people dislike certain parts of the city or even avoid it, e.g., for its smell, noise, rowdy people etc. They can therefore restrict their movement or their will to move through certain parts of the city and, in some cases, contribute to some people becoming more intolerant towards those places and people occupying it, leading to dissatisfaction and pressures on the city administration to reduce what they see as a cause of nuisance.

However, perceptions of incivilities and actual incivilities need not overlap. Studies on the fear of crime have long ago revealed that there exists a (sometimes large) discrepancy between

\footnotetext{
5 The new symbolism of corporate/consumption infrastructures is also addressed in the work of urban sociologists (Zukin 2005; Gottdiener 2005) and of cultural geographers (Thrift 1996; Firey 2005; Anderson and Harrison 2010), to which cultural criminologists often refer in their writings.

6 For example, in Rome, the area around the House of Representatives (Palazzo Montecitorio) combines very old historical buildings (including the Pantheon and many other Ancient Roman monuments, along with Baroque churches and statues) with shopping malls (mainly, in Corso Como and via di Campo Marzio), expensive boutiques and design shops.
} 
the actual crime rates (and actual probability one would become a victim of crime) and people's perceptions (fears) that they are likely to become a victim of crime. What those studies found, moreover, is that there exists a bigger connection between the fear of crime and incivilities than that between fear of crime and crime itself. In other words, it is people's perceptions of disorder (incivilities) that triggers their alarm and "fear of crime" (Goffman 1971; Hope and Hough 1988; Young 1999). Depending on the local culture and contextual factors, including the relative absence of law enforcement or signals of control, certain signs or episodes of disorder alongside crime become perceived in individual communities as "signal crimes" (Innes 2014) and it is this that makes people uncomfortable or fearful and stimulates them to react in a certain way. In other words, although perception is based on incomplete, unverified and thus unreliable information, it steers human behaviour and is for most practical purposes equated with reality. ${ }^{7}$

Perceptions of disorder therefore matter. But what are they? Perception has been described as "the organisation, identification, and interpretation of a sensation in order to form a mental representation" (Schacter, Gilbert, Wegner and Nock 2014: 130) and more widely to understand the environment. In the context of disorder or incivilities, this would then mean the organisation, identification and interpretation of sensory information in order to form a mental representation of "disorder".

However, we may recognise or "identify" and interpret something as a sign of disorder or nuisance simply because were brought up in, or are accustomed to, a different space - space that in our heads remains as a sort of paradigmatic order space against which we judge deviations. When we are faced with something entirely different, we compare this new space with our paradigmatic order space and designate encountered deviations as "disorder". City folk, long-term urbanites or those being born and raised in the city may therefore "see" or perceive less disorder that people who have moved into the city (e.g. for work) from suburban differently ordered spaces. A study by Félonneau (2004), for example, revealed that the attitude one holds toward the city is important, since those who dislike or reject the city (urbanophobes) tend to overestimate uncivil behaviour in the city. In contrast, those favourably inclined towards the city (urbanophils) tend to identify with the city and underestimate the frequency of uncivil behaviour. ${ }^{8}$ Our perceptions of (and attitudes towards) space can therefore mould or filter our perceptions of incivilities. This paradigmatic order space need not be some geographically different place though; it might be the same territory but from a different time, a bygone era. We may be remembering how this place and things in it "used to be" and holding our memory or image of the (often idealised) place as our measuring stick.

How we perceive and understand objects does not happen in a vacuum. One's knowledge of the world around them is of "paramount importance in understanding what and how [one] perceives events and stimuli and what they remember about them" (Kapardis 2005: 25; Clifford and Bull 1978). Perceptions of space are socially, ${ }^{9}$ psychologically, morally ${ }^{10}$ and culturally (co)constructed, which is reflected also in the way these perceptions are studied. Urban sociologists, psychologists, geographers as well as city planners have collected and studied people's perceptions of space in different ways. Some have gathered people's perceptions of space directly, for example, through interviews carried out with the aid of cognitive mapping,

\footnotetext{
${ }^{7} \mathrm{http} / / /$ www.businessdictionary.com/definition/perception.html. That there is a frequent mismatch between perceptions of anti-social behaviour and an objective measure thereof has also been observed by researchers who drafted the 2010 Home Office Research Report 34 (see Mackenzie, Bannister, Flint, Parr, Millie and Fleetwood, 2010). ${ }^{8}$ Félonneau used a sample of 150 students who had lived in the city of Bordeaux for at least 3 years. A later study similarly found that people living in Paris are less annoyed by environmental nuisance (physical incivilities), the use of cars and other (more social) incivilities, than people living in other French provincial cities, possibly due to a more positive social representation of the urban environment (Robin, Matheau-Police and Couty 2007).

${ }^{9}$ Social psychologists remind us that while individual experience and perceptions are not to be dismissed, we have to remember that "nearly everything which a person knows they have learnt from another, either through their accounts, or through the language which is acquired, or the objects which are used". The roots of our knowledge are "submerged in the way of life and collective practices in which everyone participates" and it is this mutual interaction in which significant knowledge and beliefs originate (Flick 1998: 216 (all quotes)).

10 Dixon, Levine and McAuley (2006) claim that incivilities are the product of the moral rules that apply to a specific urban space (or of the social construction of public space).
} 
which is based on the respondents' graphical (affective and experiential) perception of certain urban environments. Other have collected them indirectly through, for instance, the analysis of texts, paintings, fiction, films and other media, which are thought to reflect (dominant) representations of urban space (Wirth-Nesher 2001; Hubbard 2006).

Although it is sometimes difficult in our Western society to disentangle consumerist values from (other) cultural factors, people's perceptions of space are not always explained by reference to economic or consumption considerations. Such examples involve cases where specific architecture plays a symbolic role in a particular urban space. Historical buildings or monuments, for example, convey different (non-consumerist) messages and signs to individuals - signs that are related to, or mediated through, their history and the national or local/city culture. ${ }^{11}$ History and culture, alongside consumption, therefore play a role in how people construct and understand space around them. Schut, Nas and Hettige (2011) have shown, for example, that the meanings given by people to particular places and buildings in the city of Colombo, Sri Lanka, and their associated emotions are very much influenced by the local history and culture of the city, for example, by its past as a Portuguese and Dutch colony and by its relatively recent history of civil war and terroristic attacks.

Another such culturally mediated value is aesthetics. One's culturally conveyed representations of aesthetics (i.e. of what is beautiful) inform one's ideas of visually pleasant public spaces. The presence of things or groups of people who are not "stylish" enough or are considered aesthetically disturbing in those same spaces may thus influence one's perceptions of disorder and spark law enforcement responses - either indirectly (through pressure on the city officials) or directly (where perceptions are those of the police). The sense of aesthetics is of course something very subjective. Even within the same culture or the same in-group, individuals may differ in their opinion of what is "beautiful" or "ugly". What is relevant in view of the social control is the power to uphold one group's aesthetic vision to the detriment of others. While different groups using the same space have different definitions of "aesthetic order", the "aesthetic of authority" (Ferrell 1996) becomes the norm or measuring stick, while the aesthetic orders of minorities tend to be marginalised or even criminalised, especially in certain areas of the city (Millie 2016). ${ }^{12}$

The homeless, for example, are a sore spot for many a city mayor, particularly when present in certain urban spaces. Not only do they not contribute to the consumption and have therefore no financial "added value" for the city, they are also often considered unsightly and their everyday behaviour a nuisance, something that city centres aimed at attracting tourists and gentrified areas where up-market consumers live would prefer to remove or at least displace. Apart from the zoning already mentioned, social control measures against the homeless stretch from outright criminalisation to "softer" situational measures meant to discourage or disable the homeless from engaging in their activities (basically from being homeless) at their doorstep. The so-called defensive architecture stretches from inch-high studs at the entrance areas to slanted bus benches and windowsills, from wall and ground spikes to park benches with armrests (the purpose of which is not really to rest arms but to partition the bench and prevent people from lying down). The homeless are progressively deemed unsightly or aesthetically challenging, to be tolerated only when invisible or displaced to less visible or important parts of the city (Peršak 2015), similar to Davis' $(1990,1998)$ famous account of "defensive space" and its effects in Los Angeles. The neo-liberal, consumer-oriented vision or politics of a contemporary city - or at least its most visible and deemed most important, and hence the most policed, parts - goes hand in hand with the mainstream aesthetics and is thus easily supported by a large part of city dwellers, regardless of their socio-economic status.

\footnotetext{
11 The idea that landscapes are to be read through their culture and history has been traced back to Carl Sauer (1925) and his Berkeley School of cultural geography (for a review of the latter see Jackson (1989) and Hubbard (2006)). That various symbols are conveyed through, among others, urban architectures as a result of the specific city history and culture has been further elaborated by urban symbolic ecology (e.g. Nas 2011).

${ }^{12}$ An abandoned car filled with plants, to use Millie's (2016: 14) example, may be considered and celebrated as an art installation in one city area and a traffic violation in other commercial urban districts.
} 
The importance of aesthetics and its influence on societal perceptions and law enforcement of nuisance also emerges from the results of two comparative studies that we previously conducted. For example, the comparative research addressing the societal attitudes and law enforcement responses to the incivility or nuisance of street prostitution in different city areas of Birmingham (specifically, the wards of Ladywood, Sparkbrook, and Soho and Lozells), the Brussels Capital Region (the municipalities of Ixelles, City of Brussels and Schaerbeek) and Milan (the zones of Porta Nuova, Ticinese-San Lorenzo, and Loreto and Buenos Aires) has shown that in certain wealthy areas of the centre of Milan there is a higher intolerance towards the nuisance of street prostitution than intolerance exhibited in the spaces of the other two considered cities, even though these spaces are similar in terms of regenerated architectures and of socio-economic composition of their residents. Such intolerance may have (among other factors) also something to do with the fact that street prostitutes in certain well-off areas of Milan are considered to have a "socially unacceptable" aesthetic style, which offends and undermines residents' life quality (Di Ronco 2014).13

The relevance of people's aesthetic styles in the shaping of law enforcers' representations of nuisance emerged also from a study where we investigated the nuisance of public drunkenness in two nightlife locations ${ }^{14}$ of Ghent, Belgium and Trento, Italy (Di Ronco 2016). In opposition to the legal normative definition of alcohol-related nuisance given by the Ghent police officers, law enforcers in Trento associated the nuisance of public drinking and drunkenness with the presence in the night-time area of specific societal groups (including immigrants, punks and homeless), which presented, at least for some of the interviewed police officers, some specific aesthetic features, such as "large, broad and strong build" (when referring to immigrants) and "shabbily dressed" (when addressing homeless). One Trento police officer, moreover, also considered the aesthetic styles of, particularly, punks to be in conflict with the aesthetics of the nightlife location or, more precisely, with the beauty of the architectures and historical buildings present in the area (Di Ronco 2016).

The idea that city centres have a specific aesthetic, which has to be "protected" by powerful majorities against the presence of poorly dressed groups as well as against physical incivilities, also emerges from a recent judicial case, in which the Tribunal of Bologna condemned an internationally recognised street artist (AliCè) for the offence of criminal damage for her having written a graffito in the city centre of Bologna. Although the judge in her reasoning conceded that the concerned graffiti undoubtedly qualifies as public art, she stated that it conflicts with, and opposes to, the "extraordinary beauty" of that historical area (Marceddu 2016).

This also brings us to the question of whose perceptions matter the most, in particular for social control? Are they the ones of the (ethnic) majority? The ones of dominant groups, be they economic or political? Are they of the mayor and city council as city administrators? Of the police? Who has the power to label something as deviant, to see something as disorder?

\subsection{Perceptions of incivilities and the regulation thereof}

Those seeking the primary explanation for contemporary social control in neoliberalism would focus on its economic dimensions, on financial considerations as being the driving force behind urban city control of incivilities. In this light, the economic elites (in conjunction with the political ones, governing the city) and their perceptions of what is a nice, beautiful, orderly space and what is disorder would determine the types and the severity of regulation behind it. Gentrified spaces come to express the cultural and aesthetic values of the new middle class (Bridge 2001, 2006), as despite the existence of different tastes among different societal groups,

${ }^{13}$ As recently argued by Crocitti and Selmini (2016), most of the Italian municipalities, which have enacted administrative orders against uncivil behaviour, have penalised street prostitution. Many of these orders, moreover, have addressed the behaviour and especially the "appearance" of street prostitutes (or the way they are dressed), which are considered "threats to urban safety and 'public decency', and a situation that creates a feeling of insecurity in citizens living or passing nearby" (Crocitti and Selmini 2016: 9).

14 The selected nightlife locations were the Vlasmarkt and the Oude Beestenmarkt, in Ghent. In Trento, they were the area around the Santa Maria Maggiore Square and the one of via Roma, via delle Orfane and vicolo Colico. 
the new middle classes tend to present their tastes as the legitimate ones and impose them on others (Featherstone 2007). ${ }^{15}$ Those with power to define what is considered "legitimate" also have the power to label others as deviant when those others do not share their vision of aesthetics or engage in activities that are not to the taste of the former.

However, the elites or the powerful cannot completely set the tone of a specific urban social control, unless backed up by other city residents with voting rights. Most mayors and city councils democratically depend on their electorate every few years, so what people in general think matters to them. In Rome, for example, deep concerns of citizens about the high and increasing level of physical disorder in the capital have led all five candidates who have recently run for mayor at the municipal elections to include in their political programmes for the next five years measures aimed at reducing urban deterioration (Corriere della Sera 2016). The mayor of Verona justified the enactment of a local order, prohibiting people to give food to the homeless (who have mostly been identified as refugees) in the areas of the city centre, on the basis of the many complaints of urban physical disorder (mostly litter, said to be left behind by homeless) received from residents (Globalist 2014). In the municipality of Tongeren, which is situated in the Flemish Region of Belgium, the concerns of citizens over the presence of dog mess on the streets (which was indicated by a local survey as the major source of annoyance) has also led the elected representatives to introduce, and harshly enforce, administrative fines (Damiaans 2009). The response need not always be repressive though. Following the opinion of citizens, city administrators may also decide not to implement exclusionary or penalising decisions against uncivil behaviour. The Bristol City Council, for example, opened an online consultation to ask residents for their views on whether to remove Banksy's graffiti, and then acknowledged the result of this consultation by not removing it (Millie 2008).

While taking people's perceptions of what disorder is, and what it is not, seriously is important, it is equally essential - for the legitimate regulation on its basis - to understand how these perceptions are formed and that perceptions need not correspond to reality. ${ }^{16}$ Here, criminological/psychological studies would have a lot to add; unfortunately, they are still rather scarce (Franzini et al. 2008; Heap 2010). Franzini et al. (2008: 83) observe that "[t]heoretical explanations and empirical evidence of how disorder is perceived and its relation to independently observed measures of disorder are rare", which is surprising considering the importance of perceptions for the so-called zero tolerance policing. The latter, theoretically based on the "broken windows theory" (Wilson and Kelling 1982), clamped down hard on visible signs of disorder so that they do not grow into more serious crime. However, disorder seems to have been taken initially as something objective and it was not until later that researchers started pointing out the subjective elements of it (e.g. Whitehead, Stockdale and Razzu 2003; Lemieux 2005). In an important study, Sampson and Raudenbush (2004), for example, investigated how individuals perceptions of disorder are formed in Chicago neighbourhoods and came to the finding that they are shaped not only by observable conditions of disorder but also by neighborhoods' racial and socioeconomic composition. Atkinson and Flint (2003) observed that perceptions of disorder varied within neighbourhoods, mentioning that the levels of neighbour support and the length of residence were crucial factors affecting these perceptions. Similarly, Mackenzie et al. (2010) proposed that perceptions of anti-social behaviour are a matter of interpretation and that the reason for people's different interpretations lies in social connectedness. Property type has also been found to influence

\footnotetext{
15 A "typical" gentrifier still comes from middle classes, although the term has seen some significant expansion in the last decade. While previously it was the young, single, childless professionals who tended to enjoy the city and were presented as the driving force of gentrification, it is now progressively also middle-class families raising children in the city who find living in the inner city a good way to combine "careerism and familism" (Karsten 2003: 2582) and, even more recently, the super-rich who drive further gentrification (Doucet 2014a).

16 In a recent study by eCrime (2016), researchers studying residents' perceptions of urban (physical and social) disorder in different areas of Trento and comparing them with objective indicators (as recorded by law enforcers) found that while in most neighbourhoods they tended to match, in some other neighbourhoods (specifically, in the neighbourhoods of Meano and Sardagna) residents' perceptions of disorder where higher than expected on the basis of the reported objective levels of disorder.
} 
perceptions of disorder (Flint et al. 2007), as has the media (e.g. Reiner 2007; Peršak 2007b; Heap 2010). Franzini et al. (2008) examined how people of Baltimore perceive disorder using a similar methodology as Sampson and Raudenbush (surveys, systematic social observations, census data, and police records) and also found that visual cues of disorder are ambiguous and that perceptions of disorder are formed not only on the basis of the observed disorder but also on the basis of individual characteristics of residents and neighbourhood social structure. In contrast to the findings in Chicago, their findings, however, also indicated that neighbourhood poverty and not neighbourhood racial composition affected perceptions of disorder in Baltimore. They suggest that this shows that the influence of racial segregation on perception of disorder is imbedded in the larger historical context.

Doucet (2014b) similarly observed - although in the context of the study on gentrification that people living in different cities differently perceive urban transformations. While, for example, in the UK gentrification was perceived as having to do with the changing classes of residents, in the Netherlands it was the changing ethnic composition (rather than socioeconomic class) that was noted as "gentrification" (Doucet 2014b). This may have historical roots; it may, however, also have to do with the current preoccupations of a specific multicultural city and times we live in; for example, with the current refugee crisis, post-2008 financial crisis and the consequent rise of populism and observed increased intolerance and sensitivity toward foreigners and immigrants. Similarly to history, wider social and cultural 17 contexts therefore provide filters through which we perceive urban space and transformations taking place within it, including those towards greater (in)civility.

\subsubsection{Gentrification as a medium?}

This alerts us the importance of incorporating the concept of gentrification more strongly into the realm of social control and, by consequence, into (mainstream) criminology, criminal policy and criminal justice studies, where it is currently not given sufficient attention. Perceptions of space are not static and can change with the transformations of the public space, e.g. due to the prevalent gentrification, observed in many Western cities. Many cities have coupled gentrification processes with rebranding campaigns and punitive strategies towards incivilities in an effort to change the image of the city into, for example, "safe" or "safer" cities and make them thus more attractive to young professionals, families and tourists (Belina and Helms 2003; Bannister, Fyfe and Kearns 2006), such as in the case of Stoke-on-Trent's "cultural quarter", illustrated by Jayne (2000). These rebranding campaigns have also aimed at attracting investors into the city, including the major leisure corporations involved in the business of the Night-Time Economy. Some cultural criminologists (e.g., Hayward 2004), geographers and urban studies scholars working in the field of criminology (e.g., Bannister, Fyfe and Kearns 2006) and scholars from other fields contributing to the literature on the Night-Time Economy (e.g., Chatterton and Hollands 2003; Hobbs, Hadfield, Lister and Winlow 2003, 2005) focus particularly on this economic dimension of gentrification, seeing it as an element that goes hand in hand with consumption and pleasure or as a strategy to regenerate (deprived) urban city centres and transform them mainly into shopping areas or zones of night-time entertainment. In their view, gentrification is used to create super safe environments that allow upper and middle classes to live, shop and, in certain city areas which are often subject to intensive surveillance, to spend the night drinking and partying.

However, there is more to gentrification than its purely economic side. It is interesting that the processes of gentrification often seem to be almost equally supported by the well-off (buying property in new, gentrified areas) as by the more general public, who sees these processes in terms of regeneration of the city rather than in terms of social injustice or displacement of the poor, which is aided by the positive media accounts (e.g. Cravatts 2007;

17 Innes (2014) has underscored the importance of considering the specific cultural context of the community under study to enhance our understanding of the events that act as a signal of the risk of crime and disorder (as opposed to other events, which are not perceived as threats to the collective security). 
Buntin 2015; Gillespie 2015; Hartley-Brewer 2015). As the end result of gentrification is often newer, shinier, better-looking and "safer" urban spaces than their previous versions, it is welcomed by city dwellers of varied socio-economic status, ${ }^{18}$ tourists, business owners and economic elites alike. The fact that gentrification is almost equally driven by economic factors as it is by aesthetic considerations seems to be key in the legitimisation processes of urban social control - and it is this aspect of gentrification that, we would argue, should attract more criminological interest.

This does not mean, however, that the gentrification processes are never met with opposition, or with a successful one. A nice example of the residents' opposition to plans of gentrification is Berlin Tempelhof, a former Nazi Airport and concentration camp that has later been converted into a city park, where different societal groups tend to gather and spend their leisure time, do sports, engage in cultural activities or simply hang about. It has also been a very popular location for art installations and has recently been used as a shelter for refugees. In a 2014 referendum, the citizens opposed to the proposal of converting the park into a building site. Among other reasons, people thought it was "insensitive" to allow construction works and promote gentrification on a site "whose history should never been forgotten" (Hilbrandt 2016: 9). Similar example is one of Metelkova City in Ljubljana, Slovenia. Metelkova City Autonomous Cultural Center (or "Metelkova", as it is simply referred to) comprises an area, located alongside the Metelko street, which in socialist times housed the military base of the Yugoslav army.19 When the Yugoslav People's Army left Slovenia in the autumn of 1991, its former military barracks became a refuge for alternative artists, craftsmen and young people, some of whom squatted it in 1993, when the city government tried to demolish Metelkova. They attempted to evict the squatters, but were met with fierce opposition from various groups and individuals, intellectuals and youth, who eventually, after years to struggle, won. Now it has become an important part of Ljubljana's night-time offer, a tourist attraction even, housing art galleries and studios, several clubs, live music spaces, offices of cultural organisations and a hostel (former prison). For Tempelhof and Metelkova to succeed in resisting more lucrative city projects, however, they needed a more widespread support by the general public. The fact that these spaces were previously spaces of oppression, historical remnants of totalitarian times, which citizens would prefer to replace with something more positive or democratic, may have had a lot to do with their perceptions of those spaces and consequently their support for new, very different, bottom-up or grassroots projects.

Although gentrification processes can be met with resistance, the mentioned examples of successful resistance tend to be exceptions, rather than rules. These projects tend to succeed only as long as they are "exceptions", spatially limited and not considered occupying "prime areas" of the city. Cities and states have been deemed justified to choose their own economic and development policies, including city-planning policies, even if their choices may sometimes seem to conflict with human rights or social justice - if they, for example, drive those with lesser means out of certain city areas. ${ }^{20}$ On average, pro-gentrification policies tend to prevail.

\footnotetext{
18 Support for gentrification policies by those with lower incomes for whom it would likely be more difficult to afford to live or continue living in new, gentrified areas may suggest a further, more psychological factor at play. Some research has shown, for example, that perceptions of disorder significantly affect residents' self-esteem and that "impoverished and deteriorating surroundings are internalised and incorporated into an individual's self-image" (Haney 2007: 992). It may be that gentrification perceived as "beautifying" the city could, conversely, increase the urbanite's self-worth and therefore receive his or her support.

${ }^{19}$ It was, however, first built in 1882 for the purposes of Austro-Hungarian Army. For more on the history and development of Metelkova City see Retina (n.d.).

${ }^{20}$ In the recent case of Garib v. The Netherlands (judgment of 23 February 2016), for example, the European Court of Human Rights (concretely, its Third Section) found no violation of the applicant's freedom to choose one's residence (Article 2 Protocol no. 4) in the case of the city of Rotterdam imposing a minimum income limit on those wishing to reside in certain inner-city areas (unless the minimum duration of residence requirement was met), which effectively prevented the applicant from residing in the area of Tarwewijk. Such gentrification measure, restricting the said freedom, was seen as serving the legitimate aim "to reverse the decline of impoverished inner-city areas and to improve quality of life generally" $(\S 110)$. Even the two dissenting judges who have found the violation in the present case, however, considered city policies striving to improve impoverished areas, including "urban planning favouring
} 
In view of the process through which perceptions of nuisance by those whose voice in the city is usually heard (voice of the gentrifiers) come to influence urban order and social control, one could conceptualise gentrification as a sort of medium, i.e. not only as a great equalising power or channel through which different socio-economic groups converge in their city development visions and garnered support for various urban social control initiatives but also as a vehicle of social control as such. Considering gentrification often results in the squeezing out of the poor, who can no longer afford to live in the city centre, and putting the "right" class or socio-economic (and ethnic) group of people (back) in, thereby transforming the inner city into a disorder-free space or at least generating the perception of disorder-free space, it can surely be seen not just as "co-existing" with social control but rather as another social control response - a seemingly non-punitive response but nonetheless an anti-incivilities measure. Through gentrification efforts leading to the creation of visually pleasing spaces of living and consumption, the dominant, high-income, gentrifier groups get the rest of city dwellers on board and align the latter's perceptions to theirs. This, in turn, provides a powerful incentive for the municipal authorities to take a specific regulatory action or adopt a specific economic or city development policy and, moreover, provides a veneer of legitimacy to those decisions. As building permissions in city centres tend to be dependent on municipal authorities, what seems like a non-criminal matter (unlike violations and administrative fines for incivilities) becomes another, albeit less visible, tool of social control.

\section{Conclusion}

In the preceding pages, we have tried to show that, and how, people's perceptions of space matter for their perceptions of incivilities, which in turn are relevant for urban social control of disorder. In short, it has been claimed that perception of and attitudes toward space play an important role in how we perceive incivilities, whether we even "see" them and how frequently we believe they occur. Perceptions of incivilities, in turn, inform the city administration of the "problem" and consequently influence the social control, regulation and enforcement of incivilities, although admittedly the perceptions of those with more power (mainstream population, majority population, those bringing financial investments to the city, those occupying gentrified areas or gentrifiers) are often listened to the most. Considering it is predominantly left to the municipal authorities to decide which incivilities to tackle and how to tackle them, this is a significant repressive tool at the disposal of the city government.

Normatively speaking, understanding people's perceptions of incivilities as well as the underlying processes that influence them should be seen as a precondition for an effective and reassuring policy against the adverse impact of incivilities on people's lives (Heap 2009). It is important therefore that perceptions and views of city dwellers are taken into account and properly addressed, and therefore that they are first properly established. The latter should include the examination of perceptions of all groups of people inhabiting the city, including those of minorities (especially ethnic minorities), of socio-economically deprived, of youth and of any other groups that tend to be marginalised and penalised by agencies of formal social control. ${ }^{21}$ Moreover, studying the perceptions of those who are directly engaged in the "business" of social control, such as the police, seems a worthwhile enterprise, as it is on the basis of their perceptions that they inform decisions on whether or not to penalise a certain "uncivil" behaviour or population.

The existing studies on the perceptions of space, particularly those relevant for social control, have mostly been interested in the mainstream or dominant perceptions of space. Urban geographers contributing to the socio-spatial criminological literature represent an

more luxurious apartments", as "unquestionably legitimate" as long as they are not linked to personal characteristics $(\S 23)$.

${ }^{21}$ Millie's attempt (2006) is a noteworthy, yet rather lonely example. His focus groups among the minority and marginalised Londoners revealed that all social groups can be anti-social, but that the anti-social behaviour of some of them remains less visible or less acknowledged, for example, the abuse the homeless receive from "the suits". 
exception as they have investigated the perceptions of those who tend to be targeted by punitive regulations (e.g., street drinkers, skaters etc.). Following their example, investigating more (or engaging more with) the perceptions of space of diverging societal groups, not only of those in power (economic or political) but also of those without power (the youth, immigrant, homeless), should be encouraged in criminology, as it may offer interesting new research directions and help explain how the city is a site of conflict and cooperation. Studying cases such as Tempelhof or Metelkova, where the city, or part of it, becomes a site of resistance and where (dominant) perceptions of such spaces need not be in conflict with alternative lifestyles or even tend to support the presence of different groups and their heterogeneous uses of urban space, can be useful to unpack and understand the societal, historical, cultural, contextual etc. factors that lead to a more liberal, less punitive approach to incivilities in the public space. Cases such as these also underline the need to understand whom our various urban spaces should serve and what they are designed or meant for, realising that answers to these questions are probably in continuous flux, to be negotiated and redefined between different urban populations who occupy or claim the right to these spaces.

Furthermore, studying how people's perceptions and representations change with gentrification or city development projects, what are the elements that contribute to the legitimising of these projects and what effects these projects bring about in terms of e.g. displacing certain groups or activities, can help deconstruct "gentrification" not only as a term within cultural theory and urban planning but also as a criminological concept in its own right, seeing it as a process (and a tool) of social control. In this light, engaging more with the gentrification scholarship, which reminds us "that behind this middle-class ideal, which is so highly sought after, there are many others who are excluded" (Doucet 2014a: 132), would seem a logical step for any socially-oriented criminological perspective and criminal policy.

In the long run, studying perceptions of space and of incivilities of various groups, and especially those of the powerful who affect the city policy against incivilities, as well as the study of gentrification and similar urban planning actions may contribute to the further development of the field of socio-spatial criminology and, more concretely, to the enhancement of the criminological understanding of disorder and its social control in the urban space. Drawing from other disciplines, such as urban geography, urban sociology, urban planning and psychology, would help us gain insights on the role of history, culture, architecture, aesthetics and contextual factors as well as attitudes and emotions in shaping people's perceptions of space (and of incivilities in it). In addition to the methods of studying perceptions of space already mentioned above (interviews with residents, observation, analysis of text, video material etc.), new communication platforms, such as social media (e.g. Facebook groups, Twitter posts, blogs), various apps and the internet more broadly, should not be neglected as they can provide a powerful tool for investigating people's underlying understanding of space and its characteristics (including incivilities), and ultimately contribute to the understanding of the social reaction against nuisance. CCTV footage can likewise be informative in assessing how people perceive certain spaces as well as incivilities, although knowing that one is under surveillance, that one is being watched, in itself modifies one's behaviour (see, e.g., Mazerolle et al. 2002) - at least at the beginning, before CCTV cameras may become banal or normalised (Goold et al. 2013). Ultimately, it may convey more about how people perceive social control mechanisms, which have been designed and physically incorporated in the urban space (CCTV) than space itself. On the other hand, it may be difficult to completely disassociate the two when relatively stable or regular surveillance of certain urban spaces becomes de facto perceived as an element of that urban space. Conceived as such, this could also enhance our understanding of perceptions of urban space as well as of social control. Finally, in light of the recent terrorist attacks in several European cities, an interesting research direction would also be to inspect whether people's perceptions of space and of minor incivilities have changed after these attacks and, if so, how. Has a more serious crime of terrorism, for example, coloured urbanites' perceptions of minor disorder and tolerance towards it? Or perhaps, conversely, made them (re)focus on the truly serious crimes instead, downplaying incivilities? 


\section{References}

Anderson, B., \& Harrison, P. (2010). Taking-place: non-representational theories and geography. Farnham: Ashgate.

Atkinson, R. (2003). Domestication by cappuccino or a revenge on urban space? Control and empowerment in the management of public spaces. Urban Studies, 40(9), 1829-1843.

Atkinson, R., \& Flint, J. (2003). Order born out of chaos? The capacity for informal social control in disempowered and 'disorganised' neighbourhoods. Policy \& Politics, 32(3): 333-350.

Bannister, J., Fyfe, N., \& Kearns, A. (2006). Respectable or respectful? (In) civility and the city. Urban Studies, 43(5-6), 919-937.

Beckett, K., \& Herbert, S. 2009. Banished: The New Social Control in Urban America. New York: Oxford University Press.

Belina, B., and Helms, G. (2003). Zero tolerance for the industrial past and other threats: Policing and urban entrepreneurialism in Britain and Germany. Urban Studies, 40(9), 1845-1867.

Bottoms, A. (2012). Developing socio-spatial criminology. In M. Maguire, R. Morgan \& R. Reiner (Eds.), The Oxford handbook of criminology, fifth ed. (pp. 450-489). Oxford: Oxford University Press.

Bridge, G. (2001). Estate agents as interpreters of economic and cultural capital: the gentrification premium in the Sydney housing market. International Journal of Urban \& Regional Research, 25(1), 87-101.

Bridge, G. (2006). It's not just a question of taste: gentrification, the neighbourhood, and cultural capital. Environment and Planning A, 38(10), 1965-1978.

Buntin, J. (2015). The myth of gentrification. http://www.slate.com/articles/news_and_politics/politics/2015/01/the_gentrification_my th_it_s_rare_and_not_as_bad_for_the_poor_as_people.html. Accessed 20 October 2016.

Chatterton, P., \& Hollands, R. (2003). Urban nightscapes: youth cultures, pleasure spaces and corporate power. London: Routledge.

Clifford, B.R., \& Bull, R. (1978). The psychology of person identification. London, Routledge \& Kegan Paul.

Coleman, R. (2005). Surveillance in the city: primary definition and urban spatial order. Crime, Media, Culture, 1(2), 131-148.

Corriere della Sera (2016, May 11). Comunali, il confronto tra i candidati sindaco su economia, cultura, decoro e nuovi progetti. 10. Qual'è la priorità per il decoro? http://roma.corriere.it/politica/cards/comunali-confronto-candidati-sindaco-problemiroma/qual-priorita-il-decoro.shtml. Accessed 4 July 2016.

Cravatts, R.L. (2007). Gentrification is good for the poor and everyone else, American Thinker, 1 Aug 2007. http://www.americanthinker.com/articles/2007/08/gentrification_is_good_for_the.html. Accessed 13 November 2016.

Crocitti, S., \& Selmini, R. (2016). Controlling immigrants: the latent function of Italian administrative orders. European Journal on Criminal Policy and Research. doi: 10.1007/s10610-016-9311-4.

Damiaans, R (2009, April 21). Hondenpoep is niet alleen een bron van ergernis, het is ook veel schadelijker dan gedacht. Het Belang van Limburg, p. 6.

Davis, M. (1990). City of quartz: excavating the future in Los Angeles. London: Verso.

Davis, M. (1998). Ecology of fear: Los Angeles and the imagination of disaster. New York: Metropolitan Books.

Di Ronco, A. (2014). Regulating street prostitution as a public nuisance in the "culture of consumption": a comparative analysis between Birmingham, Brussels and Milan. In N. Peršak \& G. Vermeulen (Eds.), Reframing prostitution: from discourse to description, from moralisation to normalisation? (pp. 145-171). Maklu: Antwerp.

Di Ronco, A. (2016). Public drunkenness as a nuisance in Ghent (Belgium) and Trento (Italy). Crime, Law \& Social Change, 66(1), 59-81. 
Dixon, J., Levine, M., \& McAuley, R. (2006). Locating impropriety: street drinking, moral order, and the ideological dilemma of public space. Political Psychology, 27(2), 187-206.

Doucet, B. (2014a). A process of change and a changing process: introduction to the special issue on contemporary gentrification. Tijdschrift voor Economische en Sociale Geografie, 105(2), 125-139.

Doucet, B. (2014b). The individual geographies of gentrification: between emancipation and conflict. Presentation to Dynamiques démographiques bruxelloises, 28 November 2014. http://demographie.be/wp-content/uploads/2014/10/20141128_DemogrBXL_09_BD.pdf. Accessed 12 June 2016.

eCrime (2016). eSecurity. Indagine sulla sicurezza oggettiva e soggettiva nel comune di Trento: i quattro round a confronto. Vittimizzazione, senso di insicurezza e percezione del disordine urbano dei cittadini di Trento $\begin{array}{lllll}\text { da ottobre } & 2012 & \text { a } & \text { marzo }\end{array}$ http://www.esecurity.trento.it/images/pdf/Rapporto\%20in\%20sintesi_eSecurity_01.04.2 016.pdf. Accessed 20 June 2016.

Engle Merry, S. (2004). Spatial governmentality and the new urban social order: controlling gender violence through law. In E. McLaughlin, J. Muncie \& G. Hughes (Eds.), Criminological perspectives: essential readings, second ed. (pp. 467-484). London: Sage.

Félonneau, M.-L. (2004). Love and loathing of the city: urbanophilia and urbanophobia, topological identity and perceived incivilities. Journal of Environmental Psychology, 24(1), 43-52.

Ferrell, J. (1995). Crimes of style: urban graffiti and the politics of criminality. In J. Ferrell \& C.R. Sanders (Eds.), Cultural Criminology (pp. 169-189). Boston: Northeastern University Press.

Ferrell, J. (1997). Youth, crime, and cultural space. Social Justice, 24(4), 21-38.

Featherstone, M. (2007). Consumer culture and postmodernism. London: Sage.

Firey, W. (2005). Sentiment and symbolism as ecological variables. In J. Lin \& C. Mele (Eds.), The urban sociology: a reader (pp. 89-96). New York: Routledge.

Flick, U. (1998). The psychology of the social. Cambridge: Cambridge University Press.

Flint, J., Casey, R., Davidson, E., Pawson, H., \& McCoulough, E. (2007). Tackling anti-social behaviour in Glasgow: an evaluation of policy and practice in the Glasgow Housing Association. Glasgow: Glasgow Housing Association.

Franzini, L., O’Brien Caughy, M., Murray Nettles, S., \& O'Campo, P. (2008). Perceptions of disorder: contributions of neighborhood characteristics to subjective perceptions of disorder. Journal of Environmental Psychology, 28(1), 83-93.

Garland, D. (2001). The culture of control: crime and social order in contemporary society. Oxford: Oxford University Press.

Gillespie, P. (2015). How gentrification may benefit the poor, CNN Money, 12 November 2015. http://money.cnn.com/2015/11/12/news/economy/gentrification-may-help-poorpeople/. Accessed 20 October 2016.

Globalist (2014, April 24). Ordinanza choc di Tosi: a Verona è vietato distribuire pasti ai senza tetto. http://www.globalist.it/Detail_News_Display?ID=57311\&typeb=0\&ordinanza-chocdi-tosi-a-verona-e-vietato-distribuire-pasti-ai-senza-tetto. Accessed 4 July 2016.

Goffman, E. (1971). Relations in public. London: Allen Lane.

Goold, B., Loader, I., \& Thumala, A. (2013). The banality of security: The curious case of surveillance cameras. British Journal of Criminology, 53(6): 977-996.

Gottdiener, M. (2005). Looking at themed environments. In J. Lin \& C. Mele (Eds.), The urban sociology: a reader (pp. 302-307). New York, Abingdon: Routledge.

Hall, S., Simon, W., \& Craig, A. (2008). Criminal identities and consumer culture: crime, exclusion and the new culture of narcissm. London: Routledge.

Haney, T.J. (2007). "Broken windows" and self-esteem: subjective understandings of neighbourhood poverty and disorder. Social Science Research, 36(3), 968-994.

Hartley-Brewer, J. (2015). The Cereal Killer rioters need to be told why gentrification is good for them. The $\quad 28$ Telegraph, 2015. 
http://www.telegraph.co.uk/news/society/11896408/Shut-up-and-eat-your-cerealgentrification-is-good-for-you.html. Accessed 20 October 2016.

Hayward, K. (2004). City limits: crime, consumer culture and the urban experience. London: GlassHouse Press.

Hayward, K., \& Hobbs, D. (2007). Beyond the binge in "booze Britain": market-led liminalization and the spectacle of binge drinking. The British Journal of Sociology, 58(3), 437-456.

Hayward, K., \& Yar, M. (2006). The "chav" phenomenon: consumption, media and the construction of a new underclass. Crime, Media, Culture, 2(1), 9-28.

Heap, V. (2009). "I don't say that bored kids hanging about are bad, but they are scary!" Exploring attitudinal factors that affect public perceptions of anti-social behaviour, Papers from the British Criminology Conference, 9, 71-91.

Heap, V. (2010). Understanding public perceptions of anti-social behaviour: problems and policy responses (Ph.D. thesis). Huddersfield, UK: University of Huddersfield.

Hilbrandt, H. (2016). Insurgent participation: consensus and contestation in planning the redevelopment of Berlin-Tempelhof airport. Urban Geography. doi: 10.1080/02723638.2016.1168569.

Hubbard, P. (2006). City. New York, Routledge.

Hobbs, D., Hadfield, P., Lister, S., \& Winlow, S. (2003). Bouncers: violence and governance in the nighttime economy. Oxford: Oxford University Press.

Hobbs, D., Hadfield, P., Lister, S., \& Winlow, S. (2005). Violence and control in the night-time economy. European Journal of Crime, Criminal Law and Criminal Justice, 13(1), 89-102.

Hope, T., \& Hough, M. (1988). Area, crime and incivility: a profile from the British Crime Survey. In T. Hope \& M. Shaw (Ed.), Communities and crime reduction (pp. 30-47). London: HMSO.

Innes, M. (2014). Signal crimes. Social reactions to crime, disorder and control. Oxford: Oxford University Press.

Jackson, P. (1989). Maps of meaning: an introduction to cultural geography. London: Unwin Hyman.

Jayne, M. (2000). Imag(in)ing a post-industrial Potteries. In D. Bell \& A. Haddour (Eds.), City visions (pp. 12-26). Harlow: Prentice Hall.

Jayne, M., \& Valentine, G. (2016). Alcohol-related violence and disorder: new critical perspectives. Progress in Human Geography, 40(1), 67-87.

Jayne, M., Valentine, G., \& Holloway, S. L. (2008). Fluid boundaries - British binge drinking and European civility: alcohol and the production and consumption of public space. Space and Polity, 12(1), 81-100.

Jayne, M., Valentine, G., \& Holloway, S. L. (2012). What use are units? Critical geographies of alcohol policy. Antipode, 44(3), 828-846.

Kapardis, A. (2005). Psychology and law: a critical introduction, second ed. Cambridge: Cambridge University Press,.

Karsten, L. (2003). Family gentrifiers: challenging the city as a place simultaneously to build a career and to raise children. Urban Studies, 40(12), 2573-2584.

Lemieux, F. (2005). Qu'est-ce qu'une incivilité? Représentations et réactions des résidants francophones des logements sociaux de la ville de Montréal. Rapport présenté à La Commission du droit du Canada dans le cadre du projet: Qu'est-ce qu'un crime? http://publications.gc.ca/site/fra/9.635033/publication.html. Accessed 7 July 2016.

Ling, S., \& Bracey, M. (1995). Squaring the one percent: biker style and the selling of cultural resistance. In J. Ferrell \& C. R. Sanders (Eds.), Cultural criminology (pp. 235-276). Boston: Northeastern University Press.

Marceddu, D. (2016). Street art, il giudice su condanna AliCè per imbrattamento: "Il valore dell'arte non è un parametro". Il Fatto Quotidiano, 26 February (Online). http://www.ilfattoquotidiano.it/2016/02/26/street-art-il-giudice-su-condanna-alice-perimbrattamento-il-valore-dellarte-non-e-un-parametro/2499343/. Accessed 4 July 2016.

Mackenzie, S., Bannister, J., Flint, J., Millie, A., \& Fleetwood, J. (2010). Research report 34, Key Implications: The drivers of perceptions of anti-social behaviour. London: Home Office. 
Martin, G. (2009). Subculture, style, chavs and consumer capitalism: towards a critical cultural criminology of youth. Crime, Media, Culture, 5(2), 123-145.

Mazerolle, L., Hurley, D., \& Chamlin, M. (2002). Social behavior in public space: An analysis of behavioral adaptations to CCTV. Security Journal, 15(3): 59-75.

Measham, F. (2004). Play space: historical and socio-cultural reflections on drugs, licensed leisure locations, commercialisation and control. International Journal of Drug Policy, 15(5), 337-345.

Measham, F., \& Brain, K. (2005). "Binge" drinking, British alcohol policy and the new culture of intoxication. Crime, Media, Culture, 1(3), 262-283.

Miller, J. A. (1995). Struggles over the symbolic: gang style and the meaning of social control. In J. Ferrell \& C. R. Sanders (Eds.), Cultural criminology (pp. 213-234). Boston: Northeastern University Press.

Millie, A. (2006). Anti-social behaviour: concerns of minority and marginalised Londoners. Internet of Journal Criminology (Online). https://docs.wixstatic.com/ugd/b93dd4_f2b6b6c7fc114d29995c4a0b504c377e.pdf. Accessed 2 Oct 2017.

Millie, A. (2008). Anti-social behaviour, behavioural expectations and an urban aesthetic. British Journal of Criminology, 48(3), 379-394.

Millie, A. (2016). Urban interventionism as a challenge to aesthetic order: towards an aesthetic criminology. Crime, Media, Culture. doi: 10.1177/1741659016631609.

Nas, P. J. M. (2011). Cities full of symbols: a theory of urban space and culture. Leiden: Leiden University Press.

Peršak, N. (2007a). Criminalising harmful conduct: the harm principle, its limits and continental counterparts. New York: Springer.

Peršak, N. (2007b). Representations of the anti-social (M.Phil. thesis in social psychology). Cambridge: University of Cambridge, Faculty of Social and Political Sciences.

Peršak, N. (2014). Norms, harms and disorder at the border: the legitimacy of criminal law intervention through the lens of criminalisation theory. In N. Peršak (Ed.), Legitimacy and trust in criminal law, policy and justice: norms, procedures, outcomes (pp. 13-34). Farnham, Burlington: Ashgate.

Peršak, N. (2015). Criminalising urban marginality: homelessness, law, and defensive architecture. Paper presented at the $15^{\text {th }}$ Annual conference of the European Society of Criminology, Porto, Portugal, 4 Sept 2015.

Peršak, N. (2016a). The rude, the bad and the ugly: penalising incivilities in Europe. In N. Peršak (Ed.), Regulation and social control of incivilities (pp. 1-10). London, New York: Routledge.

Peršak, N. (ed.) (2016b). Regulation and social control of incivilities. London, New York: Routledge.

Peršak, N. (2016c). Media representations of incivilities in the British and Flemish press. In N. Peršak (Ed.), Regulation and social control of incivilities (pp. 125-145). London, New York: Routledge.

Pleysier, S. (2015). Local governance of safety and the normalization of behavior. Crime, Law \& Social Change, 64(4-5), 305-317.

Podoletz, L. (2016). Tackling homelessness through criminalisation: the case of Hungary. In N. Peršak (Ed.), Regulation and social control of incivilities (pp. 75-91). London, New York: Routledge.

Reiner, R. (2007). Media-made criminality: the representation of crime in the media. In M. Maguire, R. Morgan \& R. Reiner (Eds.), The Oxford handbook of criminology (pp. 376-416). Oxford: Oxford University Press.

Retina. (n.d.) 100 years of Metelkova. http://web.archive.org/web/20050122024652/http://www.ljudmila.org/retina/metelkov a-katalo/100.html. Accessed 5 July 2016.

Robin, M., Matheau-Police, A., \& Couty, C. (2007). Development of a scale of perceived environmental annoyances in urban settings. Journal of Environmental Psychology, 27(1), $55-68$. 
Sampson, R.J., \& Raudenbush, S. W. (2004). Seeing disorder: neighborhood stigma and the social construction of "Broken Windows". Social Psychology Quarterly, 67(4), 319-342.

Sauer, C.O. (1925). The morphology of landscape. University of California Publications in Geography, 2(2), 19-53.

Schacter, D. L, Gilbert, D. T, Wegner, D. M, \& Nock, M. K. (2011). Psychology. New York: Worth Publishers.

Schut, M., Nas, P. J. M., \& Hettige, S. T. (2011). Emotion in the symbolic spectrum of Colombo, Sri Lanka. In P. J. M. Nas (Ed.), Cities full of symbols: a theory of urban space and culture (pp. 2754). Leiden: Leiden University Press.

Simester, A. P., \& von Hirsch, A. (2011). Crimes, harms and wrongs: on the principles of criminalisation. Oxford: Hart Publishing.

Thrift, N. (1996). Spatial formations. London: Sage.

Whitehead, C. M. E., Stockdale, J. E., \& Razzu, G. (2003). The economic and social costs of antisocial behaviour. London: London School of Economics.

Wilson, J. Q., \& Kelling, G. (1982). The police and neighborhood safety: broken windows. Atlantic Monthly 127, 29-38.

Wirth-Nesher, H. (2001). Impartial maps: reading and writing cities. In R. Paddison (Ed.), Handbook of urban studies (pp. 52-66). London: Sage.

Young, J. (1999). The exclusive society. London: Sage.

Zedner, L. (2009). Security. London, New York: Routledge.

Zukin, S. (2005). Whose culture? Whose city? In J. Lin \& C. Mele (Eds.), The urban sociology: a reader (pp. 281-289). London, New York: Routledge. 